\title{
Chemical characterization, antioxidant, anti-inflammatory and cytotoxic properties of bee venom collected in Northeast Portugal
}

\author{
Filipa Sobral $^{\mathrm{a}}$, Andreia Sampaio ${ }^{\mathrm{a}}$, Soraia Falcão ${ }^{\mathrm{a}}$, Maria João R.P. Queiroz ${ }^{\mathrm{b}}$, Ricardo C. \\ Calhelha $^{\mathrm{a}, \mathrm{b}}$, Miguel Vilas-Boas, ${ }^{\mathrm{a},{ }^{*}}$, Isabel C.F.R. Ferreira ${ }^{\mathrm{a}, *}$
}

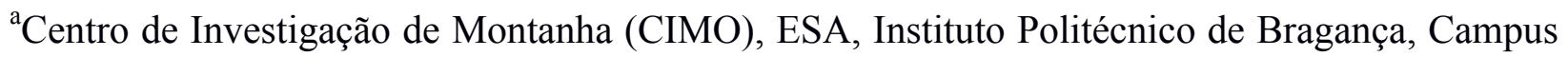
de Santa Apolónia, 5300-253 Bragança, Portugal.

${ }^{\mathrm{b}}$ Centro de Química da Universidade do Minho, Campus de Gualtar, 4710-057 Braga, Portugal.

* Authors to whom correspondence should be addressed (e-mail: iferreira@ipb.pt telephone +351-273-303219; fax +351-273-325405; e-mail: mvboas@ipb.pt telephone +351-273-303237; fax $+351-273-325405)$. 


\begin{abstract}
Bee venom (BV) or apitoxin is a complex mixture of substances with reported biological activity. In the present work, five bee venom samples obtained from Apis mellifera iberiensis from the Northeast Portugal (two different apiaries) were chemically characterized and evaluated for their antioxidant, anti-inflammatory and cytotoxic properties. The LC/DAD/ESI-MS ${ }^{\mathrm{n}}$ analysis of the samples showed that melittin was the most abundant compound, followed by phospholipase A2 and apamin. All the samples revealed antioxidant and anti-inflammatory activity but without a direct relation with any of the individual chemical components identified. The results highlight that there are specific concentrations (present in BV5) in which these compounds are more active. The BV samples showed similar cytotoxicity for all the tested tumour cell lines (MCF-7, NCI-H460, HeLa and HepG2), being MCF-7 and HeLa the most susceptible ones. Nevertheless, the studied samples seem to be suitable to treat breast, hepatocellular and cervical carcinoma because at the active concentrations, the samples were not toxic for non-tumour cells (PLP2). Regarding the non-small cell lung carcinoma, BV should be used under the toxic concentration for non-tumour cells. Overall, the present study corroborates the enormous bioactive potential of BV being the first report on samples from Portugal.
\end{abstract}

Keywords: Bee venom; apamin; melittin; phospholipase A2; antioxidant/anti-inflammatory; cytotoxic 


\section{Introduction}

Bee venom (BV) or apitoxin, produced in the venom gland of the bee (Apis mellifera), located in the abdominal cavity, is a complex mixture of substances with reported biological activity (Liu et al., 2002; Oršolić, 2009; Oršolić, 2012). The active compounds of the BV have been described as proteins and peptides (melittin (MEL), apamin (APA), adolapin, the mast cell degranulating peptide, secapin, procamine, protease inhibitor, tertiapin and other small peptides), enzymes (phospholipase A2 (PLA2), hyaluronidase, acid phosphomonoesterase, lysophopholipase and $\alpha$ glucosidase), as well as non-peptide components, such as physiologically active amines (histamine, dopamine and noradrenalin), amino acids (aminobutyric acid and $\alpha$-amino acids), sugars (glucose and fructose), phospholipids and volatile compounds (Park et al., 2010; Gajski and Garaj-Vrhovac, 2013; Liu et al., 2014). Within these mixture, the major components of BV are histamine, catecholamines, polyamines, melittin and PLA2 (Oršolić et al., 2003).

BV has been used as a traditional medicine to treat chronic inflammatory (arthritis, rheumatism and back pain) (Chang and Bliven, 1979; Kwon et al., 2001; Kim et al., 2003; Son et al., 2007; Park et al., 2008; Vasileiadou et al., 2010) and skin (Escrig et al., 1997; Han et al., 2012) diseases. In fact, the anti-inflammatory properties of BV samples from different origins such as Egypt (Amin and Abdel-Raheem, 2014), Korea (Park et al., 2007; Park et al., 2008; Lee et al., 2009), USA (Chang and Bliven, 1979) and even commercial samples (Jang et al., 2005; Moon et al., 2007; Yoon et al., 2008) have been reported in apitherapy. Furthermore, BV individual compounds have also shown the same properties, as in the case of mast cell degranulating peptide (Banks et al., 1990), MEL (Moon et al., 2006; Park et al., 2007; Srivastava et al., 2012; Rayahin et al., 2014) and PLA2 (Ximenes et al., 2012), which are related with their capacity to reduce pro-inflammatory cytokines such as tumor necrosis factor (TNF- $\alpha$ ) and interleukins (IL- 
$1 \beta$, or IL-6), as well as other inflammatory mediators including prostaglandin E2 (PGE2) and nitric oxide (NO), which are synthesized by cyclooxygenase (COX) and inducible nitric oxide synthase (iNOS), respectively. The production of these mediators has been demonstrated in several inflamed tissues involved in the pathogenesis of several diseases, such as atherosclerosis, obesity, metabolic syndrome, diabetes, neurodegenerative diseases, and several types of cancers (Nam et al., 2003; Jang et al., 2005; Janik et al., 2007; Karimzadeh et al., 2013; Mohammadi et al., 2015).

The anticancer effects of commercial BV (Xiu et al., 2002; Moon et al., 2006; Lee et al., 2007; Gajski et al., 2014; Kim et al., 2015), BV samples from Iran (Alizadehnohi et al., 2012) and Slovenia (Oršolić et al., 2003; Oršolić, 2009) and individual components such as PLA2 (Ferguson and Duncan, 2009) and MEL (Hu et al., 2006; Huh et al., 2012) have also been described. These properties are related with induction of apoptosis and necrosis (Liu et al., 2014) and cytotoxic effects in different types of cell lines, including prostate, breast, kidney, bronchial epithelium (Huh et al., 2012), lung (Putz et al., 2006), ovarian (Alizadehnohi et al., 2012), colon (Ferguson and Duncan, 2009), bladder (Ip et al., 2012), leukemic (Moon et al., 2006), cervical (Oršolić et al., 2009; Gajski and Garaj-Vrhovac, 2013; Gajski et al., 2014) and laryngeal carcinoma (Gajski and Garaj-Vrhovac, 2013), but also in non-tumor cells such as lymphocytes (Lee et al., 2007; Garaj-Vrhovac and Gajski, 2009).

Antimutagenic (Varanda et al., 1999), antinociptive (Baek et al., 2006), and radioprotective (Garaj-Vrhovac and Gajski, 2009) effects are among other bioactive properties of BV, together with the low explored antioxidant potential of this natural matrix. A few studies report the antioxidant effects of BV samples from Korea (Han et al., 2010) and USA (Rekka et al., 1990), and of PLA2 (Snyder et al., 1985). 
In the present work, five bee venom samples obtained from Apis mellifera iberiensis from the Northeast Portugal were chemically characterized and evaluated for their antioxidant, antiinflammatory and cytotoxic properties.

\section{Materials and methods}

\subsection{Samples collection}

Five distinct bee venom samples were collected between May and July of 2014 from Apis mellifera iberiensis hives located in two different apiaries near Bragança (BV1-5), in the Northeast region of Portugal. The physical distance between the two apiaries (BV1-4 in

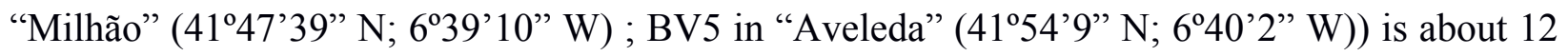
$\mathrm{Km}$. For the sample collection a BeeWhisper 0412 bee venom collector (IGK Electronics, Bulgaria) was placed at the entrance of the hive. When the honeybees covered the entire surface of the collector frame and came into contact with the wire grid, a mild electrical impulse shock $(1.8 \mathrm{~V})$ was applied. The immediate response of the honeybees was generated, and they stung the surface of the collector glass. Every 50 seconds, the device paused for additional 10 seconds. After 40 minutes of working time, the device turned off automatically. That was the maximum time applied for bee venom collection, per colony, in one session. Each sample corresponds to bee venom collected from 5 neighbor colonies. After the collection period, the bee venom was scraped off from the glass with a sharp scraper. The bee venom was then freeze-dried and stored at $-18{ }^{\circ} \mathrm{C}$ until further analysis.

\subsection{Standards and reagents}


Apamin from bee venom (purity 98.3\%) was obtained from CalBiochem (San Diego, CA, USA). Phospholipase A2 from bee venom (activity: 1775 units $\mathrm{mg}^{-1}$ solid), cytochrome $c$ from equine heart (purity $\geq 95 \%$ ), trolox (6-hydroxy-2,5,7,8-tetramethylchroman-2-carboxylic acid), lipopolysaccharide (LPS), dexamethasone, sulforhodamine B, trypan blue, trichloro acetic acid (TCA) and Tris were purchased from Sigma-Aldrich (St. Louis, MO, USA). Melittin from bee venom (purity: 67\%) was obtained from Latoxan (Valence, France). Formic acid was from Panreac (Barcelona, Spain), while HPLC grade acetonitrile was from Fisher Scientific UK (Loughborough, Leics, UK). 2,2-Diphenyl-1-picrylhydrazyl (DPPH) was obtained from Alfa Aesar (Ward Hill, USA). RAW 264.7 cells were purchased from ECACC ("European Collection of Animal Cell Culture") (Salisbury, UK) and DMEM from Hyclone (Logan, Utah, US). The Griess Reagent System Kit was purchased from Promega (Madison, WI, USA). Dulbecco's modified Eagle's medium (DMEM), hank's balanced salt solution (HBSS), fetal bovine serum (FBS), L-glutamine, trypsin-EDTA, penicillin/streptomycin solution $(100 \mathrm{U} / \mathrm{mL}$ and $100 \mathrm{mg} /$ $\mathrm{mL}$, respectively) were purchased from Gibco Invitrogen Life Technologies (California, USA). Water was treated in a Milli-Q water purification system (TGI Pure Water Systems, USA).

\subsection{Chemical characterization of the samples by LC/DAD/ESI-MS ${ }^{n}$}

The LC/DAD/ESI-MS ${ }^{\mathrm{n}}$ analyses were performed on a Dionex Ultimate 3000 UPLC instrument (Thermo Scientific, USA) equipped with a diode-array detector and coupled to a mass detector. The chromatographic system consisted of a quaternary pump, an autosampler maintained at $5{ }^{\circ} \mathrm{C}$, a degasser, a photodiode-array detector, an automatic thermostatic column compartment. The chromatographic separation was carried out according with previously described work with some modifications on a XSelect CSH130 C18, 100mm $\times 2.1 \mathrm{~mm}$ id, $2.5 \mu \mathrm{m}$ XP column (Waters, 
Milford, MA) and its temperature was maintained at $30{ }^{\circ} \mathrm{C}$. The mobile phase consisted of (A) $0.1 \%(\mathrm{v} / \mathrm{v})$ formic acid in water and (B) $0.1 \%(\mathrm{v} / \mathrm{v})$ formic acid in acetonitrile, which were previously degassed and filtrated. The solvent gradient started with $100 \% \mathrm{~A}$, reaching $60 \% \mathrm{~B}$ at $12 \mathrm{~min}, 100 \% \mathrm{~B}$ at $15 \mathrm{~min}$ and return to the initial conditions. The flow rate was $0.3 \mathrm{~mL} / \mathrm{min}$, with an injection volume of $40 \mu \mathrm{L}$. Spectral data for all peaks were accumulated in the range 190-500 $\mathrm{nm}$. Cytochrome $c$, as the internal standard (IS), was prepared in deionized water at the concentration of $25 \mu \mathrm{g} / \mathrm{mL}$. For the analysis, the lyophilized bee venom ( $3 \mathrm{mg}$ ) was dissolved in $10 \mathrm{~mL}$ of internal standard. Each sample was filtered through a $0.2 \mu \mathrm{m}$ nylon membrane (Whatman). Bee venom quantification was achieved using calibration curves for apamin (2-60 $\mu \mathrm{g} / \mathrm{mL} ; \mathrm{y}=0.032 \mathrm{x}+0.012)$, phospholipase $\mathrm{A} 2(4-120 \mu \mathrm{g} / \mathrm{mL} ; \mathrm{y}=0.042 \mathrm{x}+0.045)$, melittin (21$335 \mu \mathrm{g} / \mathrm{mL} ; \mathrm{y}=0.032 \mathrm{x}+0.133)$. The standard solutions were prepared by dissolving them in IS solution for the desire concentration.

The mass spectrometer was operated in the positive ion mode using Linear Ion Trap LTQ XL mass spectrometer (Thermo Scientific, San Jose, CA, USA) equipped with an ESI source. Typical ESI conditions were nitrogen sheath gas $35 \mathrm{psi}$, spray voltage $3.5 \mathrm{kV}$, source temperature $300{ }^{\circ} \mathrm{C}$, capillary voltage $20 \mathrm{~V}$, and the tube lens offset was kept at voltage of $74 \mathrm{~V}$. The full scan covered the mass range from $\mathrm{m} / \mathrm{z} 50$ to 2000 . The collision energy used was 30 (arbitrary units). Data acquisition was carried out with Xcalibur ${ }^{\circledR}$ data system (Thermo Scientific, San Jose, CA, USA).

\subsection{Evaluation of antioxidant properties}

The BV samples were dissolved in water at $5 \mathrm{mg} / \mathrm{mL}$ and then submitted to further dilutions from 5 to $0.02 \mathrm{mg} / \mathrm{mL}$. DPPH radical-scavenging activity was evaluated by using an ELX800 
microplate reader (Bio-Tek Instruments, Inc; Winooski, VT, USA), and calculated as a percentage of DPPH discolouration using the formula: $\left[\left(\mathrm{A}_{\mathrm{DPPH}}-\mathrm{A}_{\mathrm{S}}\right) / \mathrm{A}_{\mathrm{DPPH}}\right] \times 100$, where $\mathrm{A}_{\mathrm{S}}$ is the absorbance of the solution containing the sample at $515 \mathrm{~nm}$, and $\mathrm{A}_{\mathrm{DPPH}}$ is the absorbance of the DPPH solution. Reducing power was evaluated by the capacity to convert $\mathrm{Fe}^{3+}$ into $\mathrm{Fe}^{2+}$, measuring the absorbance at $690 \mathrm{~nm}$ in the microplate reader mentioned above. Inhibition of $\beta$ carotene bleaching was evaluated though the $\beta$-carotene/linoleate assay; the neutralization of linoleate free radicals avoids $\beta$-carotene bleaching, which is measured by the formula: $\beta$-carotene absorbance after $2 \mathrm{~h}$ of assay/initial absorbance) $\times 100$. Lipid peroxidation inhibition in porcine (Sus scrofa) brain homogenates was evaluated by the decreasing in thiobarbituric acid reactive substances (TBARS); the colour intensity of the malondialdehyde-thiobarbituric acid (MDATBA) was measured by its absorbance at $532 \mathrm{~nm}$; the inhibition ratio (\%) was calculated using the following formula: $[(\mathrm{A}-\mathrm{B}) / \mathrm{A}] \times 100 \%$, where $\mathrm{A}$ and $\mathrm{B}$ were the absorbance of the control and the sample solution, respectively (Fernandes et al., 2013). The results were expressed in $\mathrm{EC}_{50}$ values (sample concentration providing $50 \%$ of antioxidant activity or 0.5 of absorbance in the reducing power assay). Trolox was used as positive control.

\subsection{Evaluation of anti-inflammatory properties}

The BV samples were dissolved in water at $4 \mathrm{mg} / \mathrm{mL}$ and then submitted to further dilutions from 4 to $0.0625 \mathrm{mg} / \mathrm{mL}$. The mouse macrophage-like cell line RAW264.7 was cultured in DMEM medium supplemented with $10 \%$ heat-inactivated foetal bovine serum and glutamine at $37^{\circ} \mathrm{C}$ under $5 \% \mathrm{CO}_{2}$, in humidified air. For each experiment, cells were detached with a cell scraper. Under our experimental cell density $\left(5 \times 10^{5}\right.$ cells $\left./ \mathrm{mL}\right)$, the proportion of dead cells was less than $1 \%$, according to Trypan blue dye exclusion tests. Cells were seeded in 96-well plates 
at 150,000 cells/well and allowed do attach to the plate overnight. Then, cells were treated with the different concentrations of each of the extracts for $1 \mathrm{~h}$. Dexamethasone $(50 \mu \mathrm{M})$ was used as a positive control for the experiment. The following step was stimulation with LPS $(1 \mu \mathrm{g} / \mathrm{mL})$ for $18 \mathrm{~h}$. The effect of the tested samples in the absence of LPS was also evaluated, in order to observe if they induced changes in NO basal levels. In negative controls, no LPS was added. Both extracts and LPS were dissolved in supplemented DMEM. For the determination of nitric oxide, a Griess Reagent System kit was used, which contains sulfanilamide, NED and nitrite solutions. The cell culture supernatant $(100 \mu \mathrm{L})$ was transferred to the plate in duplicate and mixed with sulfanilamide and NED solutions, 5-10 minutes each, at room temperature. The nitrite produced was determined by measuring the optical density at $515 \mathrm{~nm}$, in the microplate reader referred above, and was compared to the standard calibration curve.

The results were expressed in percentages of inhibition of NO production in comparison with the negative control $(100 \%)$ and $\mathrm{EC}_{50}$ values (sample concentration providing $50 \%$ of inhibition of NO production) were also estimated.

\subsection{Evaluation of cytotoxic properties}

The BV samples were dissolved in water at $4 \mathrm{mg} / \mathrm{mL}$ and then submitted to further dilutions from 4 to $0.0625 \mathrm{mg} / \mathrm{mL}$. Four human tumor cell lines were used: MCF-7 (breast adenocarcinoma), NCI-H460 (non-small cell lung cancer), HeLa (cervical carcinoma) and HepG2 (hepatocellular carcinoma). Cells were routinely maintained as adherent cell cultures in RPMI-1640 medium containing 10\% heat-inactivated FBS and $2 \mathrm{mM}$ glutamine (MCF-7, NCI$\mathrm{H} 460 \mathrm{HeLa}$ and $\mathrm{HepG} 2$ cells), at $37^{\circ} \mathrm{C}$, in a humidified air incubator containing $5 \% \mathrm{CO}_{2}$. Each cell line was plated at an appropriate density $\left(7.5 \times 10^{3}\right.$ cells/well for MCF-7 and NCI-H460 or 
$1.0 \times 10^{4}$ cells/well for HeLa and HepG2) in 96-well plates. Sulforhodamine B assay was performed according to a procedure previously described by the authors (Barros et al., 2013).

For evaluation of the cytotoxicity in non-tumor cells, a cell culture was prepared from a freshly harvested porcine liver obtained from a local slaughterhouse, according to a procedure established by the authors (Abreu et al., 2011); it was designed as PLP2. Cultivation of the cells was continued with direct monitoring every two to three days using a phase contrast microscope. Before confluence was reached, cells were subcultured and plated in 96-well plates at a density of $1.0 \times 10^{4}$ cells/well, in DMEM medium with $10 \% \mathrm{FBS}, 100 \mathrm{U} / \mathrm{mL}$ penicillin and $100 \mu \mathrm{g} / \mathrm{mL}$ streptomycin. Ellipticine was used as positive control and the results were expressed in $\mathrm{GI}_{50}$ values (concentration that inhibited $50 \%$ of the net cell growth).

\subsection{Statistical analysis}

For all the experiments three samples were analyzed and all the assays were carried out in triplicate. The results are expressed as mean values \pm standard deviation $(\mathrm{SD})$. The differences between the different samples were analyzed using one-way analysis of variance (ANOVA) followed by Tukey's honestly significant difference post hoc test with $\alpha=0.05$, coupled with Welch's statistic. This procedure was carried out using SPSS v. 22.0 program. 


\section{Results and discussion}

The chemical components identified in the five studied BV samples are presented in Table 1. Melittin was the most abundant compound in all the samples, while apamin was the component at the lowest concentration (Table 1, Fig. 1). In fact, mellitin has been reported by different authors as the main constituent of BV (Park et al., 2012; Cho et al., 2013). BV2 gave the highest levels of mellitin $(86.72 \pm 0.50 \mu \mathrm{g} / \mathrm{mL})$, phospholipase A2 $(11.36 \pm 0.18 \mu \mathrm{g} / \mathrm{mL})$ and apamin $(1.80 \pm 0.03 \mu \mathrm{g} / \mathrm{mL})$, followed by BV4. On the other hand, BV5 and, mainly, BV1 showed the lowest concentrations in all the compounds. Although the individual amount changes with the samples, it is evident that the proportion of each compound, normalized to the overall mass, is similar, with mellitin, phospholipase A2 and apamin representing, in all samples, $86 \%, 13 \%$ and $2 \%$, respectively. This stresses out that the presence of other substances in the overall mass of the bee venom varies for each sample. Additionally, samples BV1 and BV5 were both collected earlier in May, which corresponds to the beginning of the production season. This feature may influence the age of the honeybees, and therefore the apitoxin composition, since it is well known that the synthesis and composition of bee venom is age dependent, with lower melittin content found in younger bees (Dong et al., 2015).

All the samples revealed antioxidant and anti-inflammatory activity and, apparently, not related to none of the individual components identified and quantified in the samples. BV5 proved to have the highest free radicals scavenging activity, reducing power, lipid peroxidation inhibition and also the highest capacity to inhibit NO production (Table 2). Among the studied BV samples, BV5 was the unique that was collected in a different apiary. It should be highlighted that the anti-inflammatory activity of all BV samples $\left(\mathrm{EC}_{50}\right.$ values $\left.<8 \mu \mathrm{g} / \mathrm{mL}\right)$ was higher than the positive control, dexamethasone $\left(\mathrm{EC}_{50}\right.$ value $=15.5 \pm 1.96 \mu \mathrm{g} / \mathrm{mL}$; Table 2$)$. 
The lack of correlations between the concentration of mellitin, phospholipase A2 or apamin, and the results of the in vitro antioxidant and anti-inflammatory activities evidences that there are specific concentrations in which these compounds are more active. At higher or lower concentrations, the mentioned activities decrease probably due to antagonistic effects. Curiously, a pro-inflammatory effect of samples in BV3, BV4 and BV5 was observed at the lowest tested concentration (increase in the NO levels in comparison with the negative control ( $>100 \%$ at $1 \mu \mathrm{g} / \mathrm{mL}$; Figure 2). To our knowledge this kind of effect was not previously reported, being only described the inhibition of NO formation in Raw 264.7 cells by BV samples in the range of 0.1-2 $\mu \mathrm{g} / \mathrm{mL}$ (Lee et al., 2009), 0.5-2 $\mu \mathrm{g} / \mathrm{mL}$ (Moon et al., 2007), 0.5-5 $\mu \mathrm{g} / \mathrm{mL}$ (Park et al., 2007) and 1-20 $\mu \mathrm{g} / \mathrm{mL}$ (Jang et al., 2005), as in the present study (tested concentrations: 1-15 $\mu \mathrm{g} / \mathrm{mL}$ ). In vivo experiments with Lewis rats also support the anti-inflammatory effects of BV samples (Chang and Bliven, 1979; Amin and Abdel-Raheem, 2014). Regarding the antioxidant effects of BV samples, they have been related with the capacity to inhibit the lipid peroxidation process (Rekka et al., 1990) and to increase superoxide dismutase (SOD) activity (Han et al., 2010).

The studied BV samples showed similar cytotoxicity for all the tested tumour cell lines: breast (MCF-7), non-small cell lung (NCI-H460), cervical (HeLa) and HepG2 (hepatocellular) carcinoma (Table 3). MCF-7 and HeLa were the most susceptible cell lines to the action of BV samples $\left(\mathrm{GI}_{50}\right.$ values $\left.<5 \mu \mathrm{g} / \mathrm{mL}\right)$. In the case of HeLa cell line, a $\mathrm{GI}_{50}$ value in the same magnitude was reported by Orsolić (2009) for BV from Slovenia (3 $\mu \mathrm{g} / \mathrm{mL})$. Otherwise, commercial BV samples revealed lower activity against HeLa cells $\left(\mathrm{GI}_{50}=9.7 \mu \mathrm{g} / \mathrm{mL}\right.$ (Kim et al., 2015 ) and $\sim 20 \%$ of cellular viability at $60 \mu \mathrm{g} / \mathrm{mL}$ (Gajski et al., 2014). The antitumor effects of BV samples were also demonstrated by in vivo experiments (Liu et al., 2002; Oršolić, 2003). 
It should be highlighted that despite the toxicity observed for BV samples in relation to nontumour liver cells (PLP2; Table 3), at the $\mathrm{GI}_{50}$ concentrations obtained for tumour cell lines, none of the samples was toxic for PLP2, except for the case of NCI-H460 in which the cytotoxic concentrations $\left(\mathrm{GI}_{50}\right.$ values between $16.00 \pm 2.34$ and $\left.19.68 \pm 1.80 \mu \mathrm{g} / \mathrm{mL}\right)$ were higher than the ones observed in PLP2 $\left(\mathrm{GI}_{50}\right.$ values between $10.11 \pm 0.91$ and $\left.15.03 \pm 0.28 \mu \mathrm{g} / \mathrm{mL}\right)$. Therefore, the studied samples seem to be suitable to treat breast, hepatocellular and cervical carcinoma, and regarding the non-small cell lung carcinoma, it should be used under the concentration toxic for non-tumour cells. The toxicity of BV for non-tumour cells, such as lymphocytes was also previously reported by different authors (Gajski and Garaj-Vrhovac, 2008; Garaj-Vrhovac and Gajski, 2008; Mohammadi et al., 2015).

\section{Conclusions}

Overall, this study demonstrates the broad bioactive potential of BV including antioxidant, antiinflammatory and cytotoxic activities, being the first report for Portuguese samples. Despite the identification of the most abundant molecules in $\mathrm{BV}$, some other minor compounds, together with synergistic/antagonistic effects at specific concentrations, could be involved in the reported bioactivities, contributing to different results among BV samples.

\section{Acknowledgments}

The authors are grateful to the Foundation for Science and Technology (FCT, Portugal) for financial support to CIMO (PEst-OE/AGR/UI0690/2014) and R.C. Calhelha grant (SFRH/BPD/68344/2010). 


\section{References}

Abreu, R.M., Ferreira, I.C.F.R., Calhelha, R.C., Lima, R.T., Vasconcelos, M.H., Adega, F., Chaves, R., Queiroz, M.J.R., 2011. Anti-hepatocellular carcinoma activity using human HepG2 cells and hepatotoxicity of 6-substituted methyl 3-aminothieno[3,2-b]pyridine-2carboxylate derivatives: In vitro evaluation. cell cycle analysis and QSAR studies, Eur. J. Med. Chem. 46, 5800-5806.

Alizadehnohi, M., Nabiuni, M., Nazari, Z., Safaeinejad, Z., Irian, S., 2012. The synergistic cytotoxic effect of cisplatin and honey bee venom on human ovarian cancer cell line A2780cp. J. Venom Res. 3, 22-27.

Amin, M.A., Abdel-Raheem, I.T., 2014, Accelerated wound healing and anti-inflammatory effects of physically cross linked polyvinyl alcohol-chitosan hydrogel containing honey bee venom in diabetic rats. Arch. Pharm. Res. 37, 1016-1031.

Baek, Y.H., Huh, J.E., Lee, J.D., Park, D.S., 2006. Antinociceptive effect and the mechanism of bee venom acupuncture (Apipuncture) on inflammatory pain in the rat model of collageninduced arthritis: Mediation by $\alpha 2$-Adrenoceptors. Brain Res. 1073, 305-310.

Banks, B.E., Dempsey, C.E., Vernon, C.A., Warner, J. A., Yamey, J., 1990. Anti-inflammatory activity of bee venom peptide 401 (mast cell degranulating peptide) and compound 48/80 results from mast cell degranulation in vivo. Br. J. Pharmacol. 99, 350-354.

Barros, L., Pereira, E., Calhelha, R. C., Dueñas, M., Carvalho, A.M., Santos-Buelga, C., Ferreira, I.C.F.R., 2013. Bioactivity and chemical characterization in hydrophilic and lipophilic compounds of Chenopodium ambrosioides L.. J. Funct. Foods 5, 1732-1740. 
Chang, Y.H., Bliven, M.L., 1979. Anti-arthritic effect of bee venom. Agents and actions 9, 205211.

Cho, H.J., Kang, J.H., Park, K.K., Choe, J.Y., Park, Y.Y., Moon, Y.S., Chung, I.K., Chang, H.W., Kim, C.H., Choi, Y.H., Kim, W.J., Moon, S.K., Chang, Y.C., 2013. Purinergic signalling and cancer. Proteome Sci. 11, 20-26.

Dong, J., Ying, B., Huang, S., Ma, S., Long, P., Tu, X., Yang, W., Wu, Z., Chen, W., Miao, X., 2015. High-performance liquid chromatography combined with intrinsic fluorescence detection to analyse melittin in individual honeybee (Apis mellifera) venom sac. J. Chromatogr. B 1002, 139-143.

Escrig, V., Ubeda, A., . Ferrandiz, M.L., Darias, J., Sanchez, J.M., Alcaraz, M.J., Paya, M., 1997. Variabilin: a dual inhibitor of human secretory and cytosolic phospholipase A2 with anti-inflammatory activity. J. Pharmacol. Exp. Ther. 282, 123-131.

Ferguson, E.L., Duncan, R., 2009. Dextrin- phospholipase A2: synthesis and evaluation as a bioresponsive anticancer conjugate. Biomacromolecules 10, 1358-1364.

Fernandes, Â., Barros, L., Barreira, J. C., António, A.L., Oliveira, M.B.P., Martins, A., Ferreira, I.C.F.R., 2013. Effects of different processing technologies on chemical and antioxidant parameters of Macrolepiota procera wild mushroom. LWT- Food Sci. Technol. 54, 493-499.

Gajski, G., Garaj-Vrhovac, V., 2008. Genotoxic potential of bee venom (Apis mellifera) on human peripheral blood lymphocytes in vitro using single cell gel electrophoresis assay. J. Environ. Sci. Health. 43, 1279-1287.

Gajski, G., Garaj-Vrhovac, V., 2013. Melittin: a lytic peptide with anticancer properties. Environ. Toxicol. Pharmacol. 36, 697-705. 
Gajski, G., Čimbora-Zovko, T., Rak, S., Rožman, M., Osmak, M., Garaj-Vrhovac, V., 2014. Combined antitumor effects of bee venom and cisplatin on human cervical and laryngeal carcinoma cells and their drug resistant sublines. J. Appl. Toxicol. 34, 1332-1341.

Garaj-Vrhovac, V., Gajski, G., 2009. Evaluation of the cytogenetic status of human lymphocytes after exposure to a high concentration of bee venom in vitro. Arch. Ind. Hyg. Toxicol. 60, 2734.

Han, S.M., Lee, K.G., Yeo, J.H., Oh, B.Y., Kim, B.S., Lee, W., Baek, H.J., Kim, S.T., Hwang, S.J., Park, S.C., 2010. Effects of honeybee venom supplementation in drinking water on growth performance of broiler chickens. Poult. Sci. 89, 2396-2400.

Han, S.M., Lee, G.G., Park, K.K., 2012. Skin sensitization study of bee venom (Apis mellifera L.) in Guinea pigs. Toxicol. Res. 28, 1-4.

Hu, H., Chen, D., Li, Y., Zhang, X., 2006. Effect of polypeptides in bee venom on growth inhibition and apoptosis induction of the human hepatoma cell line SMMC-7721 in-vitro and Balb/c nude mice in-vivo. J. Pharm. Pharmacol. 58, 83-89.

Huh, J.E., Kang, J.W., Nam, D., Baek, Y.H., Choi, D.Y., Park, D.S., Lee, J.D., 2012. Melittin suppresses VEGF-A-induced tumor growth by blocking VEGFR-2 and the COX-2-mediated MAPK signaling pathway. J. Nat. Prod. 75, 1922-1929.

Ip, S.W, Chu, Y.L., Yu, C.S., Chen, P.Y., Ho, H.C., Yang, J.S., Huang, H.Y., Chueh, F.S., Lai, T.Y., Chung, J.G., 2012. Bee venom induces apoptosis through intracellular Ca2+-modulated intrinsic death pathway in human bladder cancer cells. Int. J. Urol. 1, 61-70.

Jang, H.S., Kim, S.K., Han, J.B., Ahn, H.J., Bae, H., Min, B.I., 2005. Effects of bee venom on the pro-inflammatory responses in RAW264. 7 macrophage cell line. J. Ethnopharmacol. 99, 157-160. 
Janik, J.E., Wania-Galicia, L., Kalauokalani, D., 2007. Bee stings - a remedy for postherpetic neuralgia? A case report. Region. Anesth. Pain M. 32, 533-535.

Karimzadeh, L., Nabiuni, M., Kouchesfehani, H.M., Adham, H., Bagheri, A., Sheikholeslami, A., 2013. Effect of bee venom on IL-6, COX-2 and VEGF levels in polycystic ovarian syndrome induced in Wistar rats by estradiol valerate. J. Venom. Anim. Toxins Trop. Dis. 19, 32-40.

Kim, H.W., Kwon, Y.B., Ham, T.W., Roh, D.H., Yoon, S.Y., Lee, H.J., Han, H.J., Yang, I.S., Beitz, A.J., Lee, J.H., 2003. Acupoint stimulation using bee venom attenuates formalininduced pain behavior and spinal cord fos expression in rats. J. Vet. Med. Sci. 65, 349-355.

Kim, Y.W., Chaturvedi, P.K., Chun, S.N., Lee, Y.G., Ahn, W.S., 2015. Honeybee venom possesses anticancer and antiviral effects by differential inhibition of HPV E6 and E7 expression on cervical cancer cell line. Oncol. Rep. 33, 1675-1682.

Kokot, Z.J., Matysiak, J., 2009. Simultaneous determination of major constituents of honeybee venom by LC-DAD. Chromatographia 69, 1401-1405.

Kwon, Y.B., Lee, J.D., Lee, H.J., Han, H.J., Mar, W.C., Kang, S.K., Beitz, A.J., Lee, J. H., 2001. Bee venom injection into an acupuncture point reduces arthritis associated edema and nociceptive responses. Pain 90, 271-280.

Lee, Y.J., Kang, S.J., Kim, B.M., Kim, Y.J., Woo, H.D., Chung, H.W., 2007. Cytotoxicity of honeybee (Apis mellifera) venom in normal human lymphocytes and HL-60 cells. Chem. Biol. Interact. 169, 189-197.

Lee, K.G., Cho, H.J., Bae, Y.S., Park, K.K., Choe, J.Y., Chung, I.K., Kim, M., Yeo, J.H., Park, K.H., Lee, Y.S., Kim, C.H., Chang, Y. C., 2009. Bee venom suppresses LPS-mediated NO/iNOS induction through inhibition of PKC- $\alpha$ expression. J. Ethnopharmacol. 123, 15-21. 
Liu, X., Chen, D., Xie, L., Zhang, R., 2002. Effect of honey bee venom on proliferation of K1735M2 mouse melanoma cells in-vitro and growth of murine B16 melanomas in-vivo. J. Pharm. Pharmacol. 54, 1083-1089.

Liu, C.C., Yang, H., Zhang, L.L., Zhang, Q., Chen, B., Wang, Y., 2014. Biotoxins for cancer therapy. Asian Pac. J. Cancer Prev. 15, 4753-4758.

Mohammadi, E., Vatanpour, H., Shirazi, F.H., 2015. Immunomodulatory effects of bee venom in human synovial fibroblast cell line. Iran. J. Pharm. Res. 14, 313-320.

Moon, D.O., Park, S.Y., Heo, Kim, K.C., Park, C., W. Ko, S., Choi, Y.H., Kim, G.Y., 2006. Key regulators in bee venom-induced apoptosis are Bcl-2 and caspase- 3 in human leukemic U937 cells through downregulation of ERK and Akt. Int. Immunopharmacol. 6, 1796-1807.

Moon, D. O., Park, S.Y., Lee, K.J., Heo, M.S., Kim, K.C., Kim, M. O., Lee, J.D., Choi, Y.H., Kim, G.Y., 2007. Bee venom and melittin reduce proinflammatory mediators in lipopolysaccharide-stimulated BV2 microglia. Int. Immunopharmacol. 7, 1092-1101.

Nam, K.W., Je, K.H., Lee, J.H., Han, H.J., Lee, H.J., Kang, S.K., Mar, W., 2003. Inhibition of COX-2 activity and proinflammatory cytokines (TNF- $\alpha$ and IL-1 $\beta$ ) production by watersoluble sub-fractionated parts from bee (Apis mellifera) venom. Arch. Pharm. Res. 26, 383388.

Oršolić, N., Šver, L., Verstovšek, S., Terzić, S., Bašić, I., 2003. Inhibition of mammary carcinoma cell proliferation in vitro and tumor growth in vivo by bee venom. Toxicon 41 , $861-870$

Oršolić, N., 2009. Potentiation of Bleomycin lethality in HeLa and V79 cells by bee venom. Arch. Ind. Hyg. Toxicol. 60, 317-326.

Oršolić, N., 2012. Bee venom in cancer therapy. Cancer Metast. Rev. 3, 173-194. 
Park, H.J., Son, D.J., Lee, C.W., Choi, M.S., Lee, U.S., Song, H.S., Lee, J.M., Hong, J.T., 2007. Hong, Melittin inhibits inflammatory target gene expression and mediator generation via interaction with IкB kinase. Biochem. Pharmacol. 73, 237-247.

Park, H.J., Lee, H.J., Choi, M.S., Song, D.J., Song, H.S., Song, M.J., Lee, J.M., Han, S.B., Kim, Y., Hong, J.T., 2008. JNK pathway is involved in the inhibition of inflammatory target gene expression and NF-kappaB activation by melittin. J. Inflamm. 5, 7-20.

Park, J.H., Kim, K.H., Kim, S.J., Lee, W.R., Lee, K.G., Park, K.K., 2010. Bee venom protects hepatocytes from tumor necrosis factor- $\alpha$ and actinomycin D. D. Arch. Pharm. Res. 33, 215223.

Park, J.H., Kim, K.H., Lee, W.R., Han, S.M., Park, K.K., 2012. Protective effect of melittin on inflammation and apoptosis in acute liver failure. Apoptosis 1717, 61-69.

Putz, T., Ramoner, R., Gander, H., Rahm, A., Bartsch, G., Thurnher, 2006. Antitumor action and immune activation through cooperation of bee venom secretory phospholipase A2 and phosphatidylinositol-(3,4)-bisphosphate. Cancer Immunol. Immunother. 55, 1374-1383.

Rayahin, J. E., Buhrman, J. S., Gemeinhart, R., 2014. Melittin-glutathione S-transferase fusion protein exhibits anti-inflammatory properties and minimal toxicity. Eur. J. Pharm. Sci. 65, $112-121$.

Rekka, E., Kourounakis, L., Kourounakis, P., 1990. Antioxidant activity of and interleukin production affected by honey bee venom. Arzneimittel-Forschung 40, 912-913.

Snyder, L.M., Fortier, N.L., Trainor, J., Jacobs, J., Leb, L., Lubin, B., Chiu, D., Shohet, S., Mohandas, N., 1985. Effect of hydrogen peroxide exposure on normal human erythrocyte deformability, morphology, surface characteristics, and spectrin-hemoglobin cross-linking. J. Clin. Invest. 76, 1971-1977. 
Son, D.J., Lee, J.W., Lee, Y.H., Song, H.S., Lee, C.K., Hong, J.T., 2007. Therapeutic application of anti-arthritis, pain-releasing, and anti-cancer effects of bee venom and its constituent compounds. Pharmacol. Ther. 115, 246-270.

Srivastava, R. M., Srivastava, S., Singh, M., Bajpai, V. K., Ghosh, J. K., 2012. Consequences of alteration in leucine zipper sequence of melittin in its neutralization of lipopolysaccharideinduced proinflammatory response in macrophage cells and interaction with lipopolysaccharide. J. Biol. Chem. 287, 1980-1995.

Varanda, E.A., Monti, R., Tavares, D.C., 1999. Inhibitory effect of propolis and bee venom on the mutagenicity of some direct-and indirect-acting mutagens. Teratog. Carcinog. Mutagen. $19,403-413$.

Vasileiadou, K., Pantazidis, G., Papadopoulou K., Ligoudistianou, C., . Kourelis, A, Petrakis, S., Masmanidou, E., Testa, T., Kourounakis, A.P., Hadjipetrou, L., Papaconstantinou, J., Yiangou, M., 2010. $\alpha 1$-Acid glycoprotein production in rat dorsal air pouch in response to inflammatory stimuli, dexamethasone and honey bee venom. Exp. Mol. Pathol. 89, 63-71.

Ximenes, R.M., Rabello, M.M., Araújo, R.M., Silveira, E.R., Fagundes, F.H., Diz-Filho, E.B.S., Buzzo, S.C., Soares, V.C.G., Toyama, D.O., Gaeta, H.H., Hernandes, M.Z., Monteiro, H.S.A., Totyama, M.H., 2012. Inhibition of neurotoxic secretor phospholipases A2 enzymatic, endematogenic, and myotoxic activities by harpalycin 2, na isoflavone isolated from Harpalyce brasiliana benth. eCAM, 1-9.

Yoon, S.Y., Kwon, Y.B., Kim, H.W., Roh, D.H., Seo, H.S., Han, H.J., Lee, H.J., Beitz, A.J., Lee, J.H., 2008. Bee venom injection produces a peripheral anti-inflammatory effect by activation of a nitric oxide-dependent spinocoeruleus pathway. Neurosci. Lett. 430, 163-168. 


\section{Figure captions}

Fig. 1. Representative chromatographic profile at $220 \mathrm{~nm}$ of A. mellifera iberiensis venom: 1apamin; 2- phospholipase A2; IS- internal standard (cytochrome C, $25 \mu \mathrm{g} / \mathrm{mL}$ ); 3-melittin.

Fig. 2. Nitric oxide production as function of concentration of $A$. mellifera iberiensis venom (BV1-5). As the production of oxide nitric is proportional to the inflammatory process, a decrease in the nitric oxide concentration corresponds to potential anti-inflammatory activity. 


\section{Table 1}

Chemical characterization of the bee venom (BV) samples by LC/DAD/ESI-MS ${ }^{\mathrm{n}}$ analysis.

\begin{tabular}{lccccc}
\hline & BV 1 & BV 2 & BV 3 & BV 4 & BV 5 \\
\hline Apamin $(\mu \mathrm{g} / \mathrm{mL})$ & $0.94 \pm 0.01^{\mathrm{d}}$ & $1.80 \pm 0.03^{\mathrm{ab}}$ & $1.61 \pm 0.17^{\mathrm{b}}$ & $1.95 \pm 0.02^{\mathrm{a}}$ & $1.25 \pm 0.04^{\mathrm{c}}$ \\
\hline Phospholipase A2 $(\mu \mathrm{g} / \mathrm{mL})$ & $4.98 \pm 0.01^{\mathrm{d}} 11.36 \pm 0.18^{\mathrm{a}}$ & $9.02 \pm 0.62^{\mathrm{c}}$ & $10.08 \pm 0.34^{\mathrm{b}}$ & $5.98 \pm 0.11^{\mathrm{d}}$ \\
\hline Melittin $(\mu \mathrm{g} / \mathrm{mL})$ & $35.64 \pm 0.09^{\mathrm{e}} 86.72 \pm 0.50^{\mathrm{a}} 70.58 \pm 3.99^{\mathrm{c}} 80.74 \pm 0.34^{\mathrm{b}} 52.20 \pm 0.66^{\mathrm{d}}$
\end{tabular}

In each row different letters mean significant differences between samples $(\mathrm{p}<0.05)$. 


\section{Table 2}

In vitro antioxidant and anti-inflammatory activities of the bee venom (BV) samples.

\begin{tabular}{lccccc}
\hline \multicolumn{7}{l}{ BV 1 } & BV 2 & BV 3 & BV 4 & BV 5 \\
\hline Antioxidant activity (EC 50 values, $\mu \mathrm{g} / \mathrm{mL})$ & & & & \\
\hline DPPH scavenging activity & $487 \pm 7^{\mathrm{b}}$ & $451 \pm 6^{\mathrm{c}}$ & $491 \pm 1^{\mathrm{b}}$ & $512 \pm 16^{\mathrm{a}}$ & $346 \pm 4^{\mathrm{d}}$ \\
Reducing power & $326 \pm 16^{\mathrm{a}}$ & $238 \pm 10^{\mathrm{d}}$ & $306 \pm 1^{\mathrm{b}}$ & $291 \pm 2^{\mathrm{c}}$ & $225 \pm 5^{\mathrm{e}}$ \\
$\beta$-carotene bleaching inhibition & $710 \pm 10^{\mathrm{b}}$ & $545 \pm 9^{\mathrm{d}}$ & $826 \pm 9^{\mathrm{a}}$ & $666 \pm 23^{\mathrm{c}}$ & $435 \pm 15^{\mathrm{e}}$ \\
TBARS inhibition & $1.45 \pm 0.08^{\mathrm{c}}$ & $1.22 \pm 0.05^{\mathrm{d}}$ & $2.38 \pm 0.20^{\mathrm{a}} 1.70 \pm 0.03^{\mathrm{b}} 1.07 \pm 0.10^{\mathrm{e}}$ \\
\hline Anti-inflammatory activity $\left(\mathrm{EC}_{50}\right.$ values, $\left.\mu \mathrm{g} / \mathrm{mL}\right)$ & & & \\
\hline NO production & $6.77 \pm 0.13^{\mathrm{b}}$ & $5.76 \pm 0.06^{\mathrm{c}}$ & $5.81 \pm 0.94^{\mathrm{c}} 7.91 \pm 0.17^{\mathrm{a}} 4.85 \pm 0.02^{\mathrm{d}}$ \\
\hline
\end{tabular}

$\mathrm{EC}_{50}$ values for antioxidant activity: sample concentration providing $50 \%$ of antioxidant activity or 0.5 of absorbance in the reducing power. Trolox $\mathrm{EC}_{50}$ values: $41 \mu \mathrm{g} / \mathrm{mL}$ (reducing power), 42 $\mu \mathrm{g} / \mathrm{mL}$ (DPPH scavenging activity), $18 \mu \mathrm{g} / \mathrm{mL}$ ( $\beta$-carotene bleaching inhibition) and $23 \mu \mathrm{g} / \mathrm{mL}$ (TBARS inhibition).

$\mathrm{EC}_{50}$ values for anti-inflammatory activity: sample concentration providing $50 \%$ of inhibition of the NO production in relation to negative control (100\%). Dexamethasone $\mathrm{EC}_{50}$ value:15.5 \pm 1.96 $\mu \mathrm{g} / \mathrm{mL}$.

In each row different letters mean significant differences between samples $(p<0.05)$. 


\section{Table 3}

In vitro cytotoxic activity of the bee venom (BV) samples.

\begin{tabular}{|c|c|c|c|c|c|}
\hline & BV 1 & BV 2 & BV 3 & BV 4 & BV 5 \\
\hline \multicolumn{6}{|c|}{ For human tumour cell lines $\left(\mathrm{GI}_{50}\right.$ values, $\left.\mu \mathrm{g} / \mathrm{mL}\right)$} \\
\hline MCF-7 (breast carcinoma) & $4.16 \pm 0.49^{\mathrm{a}}$ & $4.44 \pm 0.43^{\mathrm{a}}$ & $4.02 \pm 0.38^{\mathrm{a}}$ & $4.51 \pm 0.21^{\mathrm{a}}$ & $4.49 \pm 0.42^{\mathrm{a}}$ \\
\hline $\begin{array}{l}\text { NCI-H460 (non-small cell lung } \\
\text { carcinoma) }\end{array}$ & $16.00 \pm 2.34^{\mathrm{a}}$ & $17.68 \pm 0.53^{\mathrm{a}}$ & $18.18 \pm 0.86^{\mathrm{a}}$ & $19.68 \pm 1.80^{\mathrm{a}}$ & $17.98 \pm 0.86^{\mathrm{a}}$ \\
\hline HeLa (cervical carcinoma) & $4.54 \pm 0.22^{\mathrm{ab}}$ & $2.83 \pm 0.41^{\mathrm{c}}$ & $4.41 \pm 0.01^{\mathrm{ab}}$ & $3.51 \pm 0.81^{\mathrm{bc}}$ & $4.80 \pm 0.15^{\mathrm{a}}$ \\
\hline HepG2 (hepatocellular carcinoma) & $10.6 \pm 1.89^{\mathrm{a}}$ & $12.19 \pm 1.40^{\mathrm{a}}$ & $5.43 \pm 0.08^{\mathrm{c}}$ & $6.55 \pm 0.11^{\mathrm{bc}}$ & $9.85 \pm 0.36^{\mathrm{ab}}$ \\
\hline \multicolumn{6}{|c|}{ For non-tumor liver cells $\left(\mathrm{GI}_{50}\right.$ values, $\left.\mu \mathrm{g} / \mathrm{mL}\right)$} \\
\hline PLP2 & $15.03 \pm 0.28^{\mathrm{a}}$ & $13.86 \pm 0.10^{\mathrm{a}}$ & $10.11 \pm 0.91^{b}$ & $12.94 \pm 1.21^{\mathrm{ab}}$ & $14.66 \pm 0.66^{\mathrm{a}}$ \\
\hline
\end{tabular}

$\mathrm{GI}_{50}$ values: sample concentration achieving $50 \%$ of growth inhibition in human tumour cell lines or in liver primary culture PLP2.Ellipticine GI $5_{50}$ values: $1.21 \mu \mathrm{g} / \mathrm{mL}$ (MCF-7), $1.03 \mu \mathrm{g} / \mathrm{mL}$ (NCI-H460), $0.91 \mu \mathrm{g} / \mathrm{mL}$ (HeLa), 1.10 $\mu \mathrm{g} / \mathrm{mL}$ (HepG2) and $2.29 \mu \mathrm{g} / \mathrm{mL}$ (PLP2).

In each row different letters mean significant statistical differences along shelf life $(p<0.05)$. 


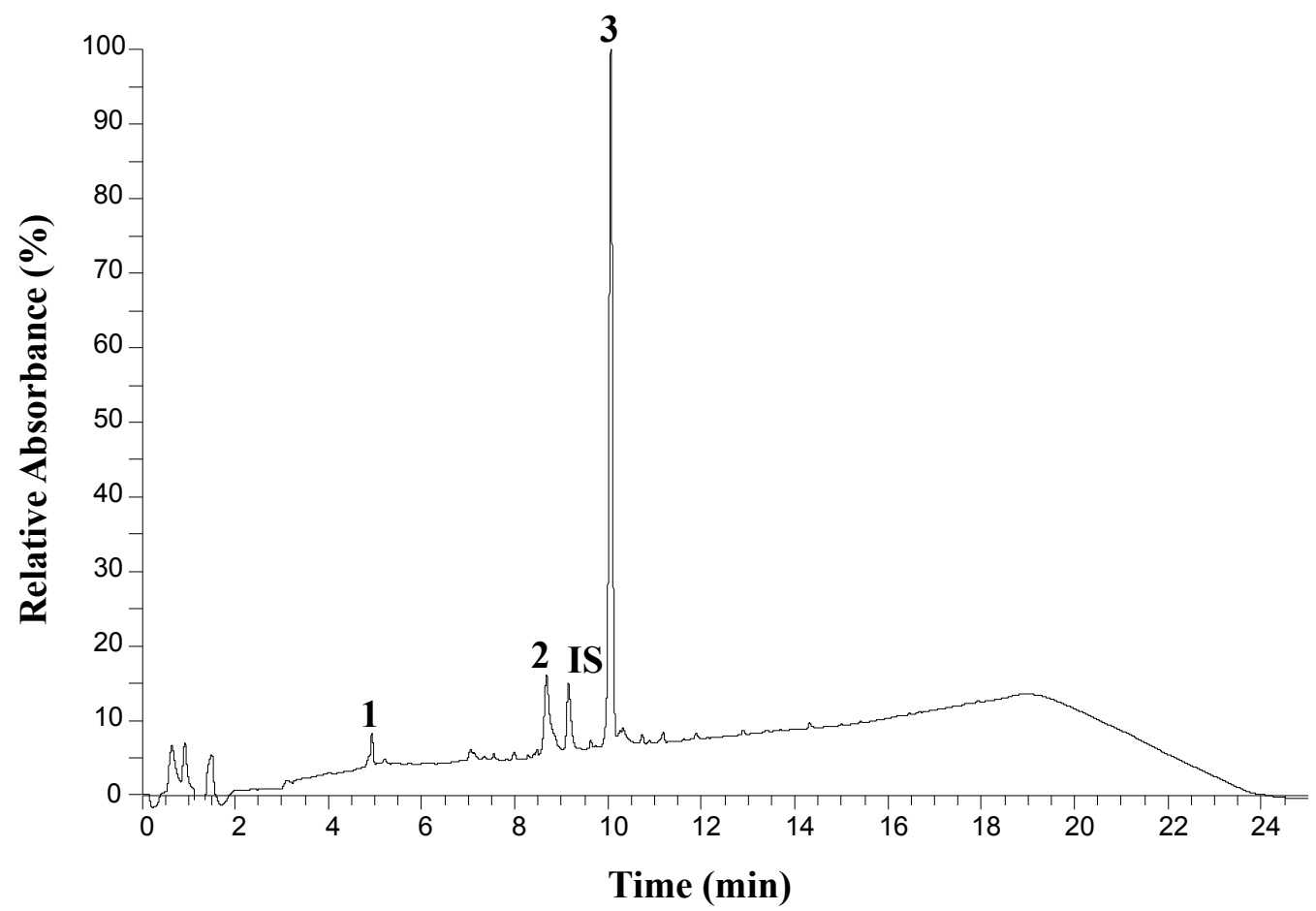

Fig. 1. 


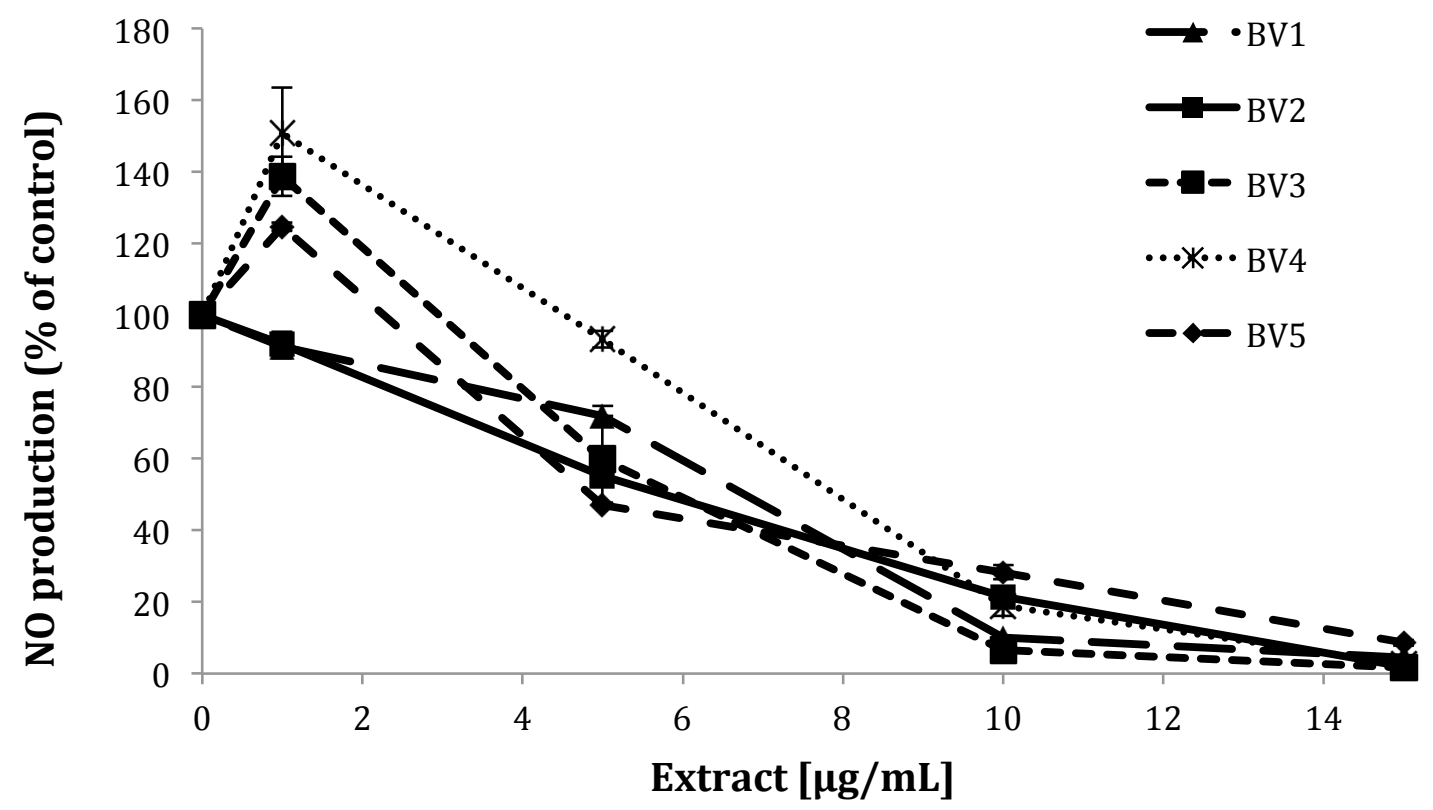

Fig. 2. 